\title{
The Medicinal Fungus Antrodia cinnamomea Regulates DNA Repair and Enhances the Radiosensitivity of Human Esophageal Cancer Cells [Corrigendum]
}

Liu YM, Liu YK, Wang LW, et al. Onco Targets Ther. 2016;9:6651-6661.

The authors have advised that the image used for Figure 3E, Panel 0 Gy 1.0 on page 6657, is incorrect. The correct Figure 3 is shown below.
The authors have advised Figure 5 on page 6658 is also incorrect. The image was intended to present all the results from the same cellular experiments in one image. To do this some adjustments were made to the Western blot bands to fit them into the same columns for drug
A

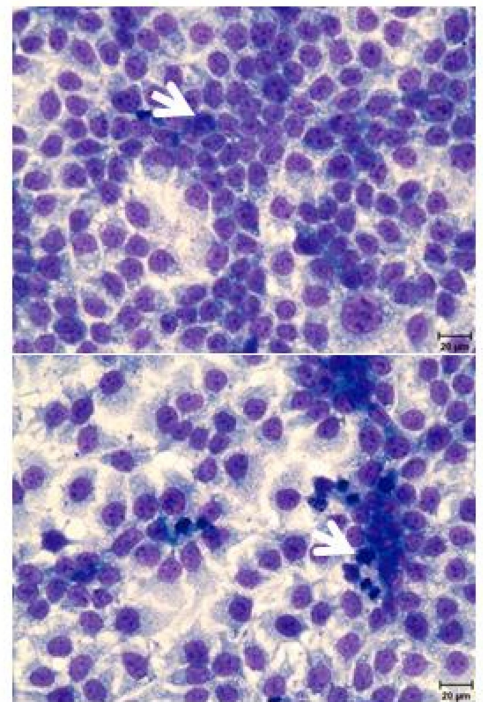

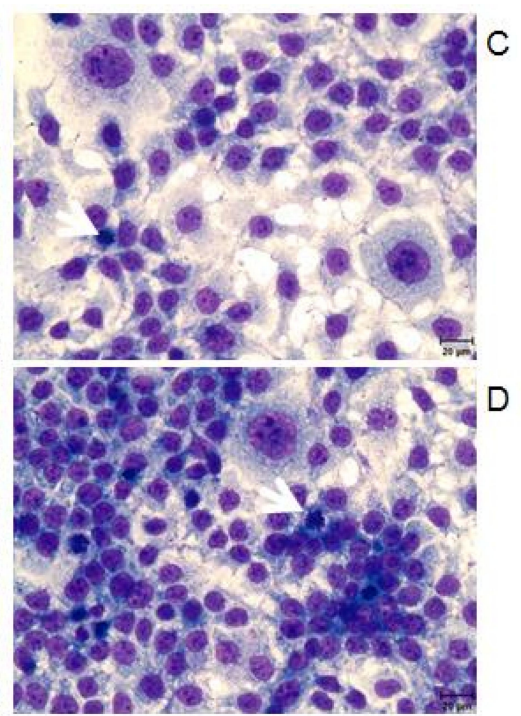

0.5

1.0

$(\mathrm{mg} / \mathrm{mL})$

0.0
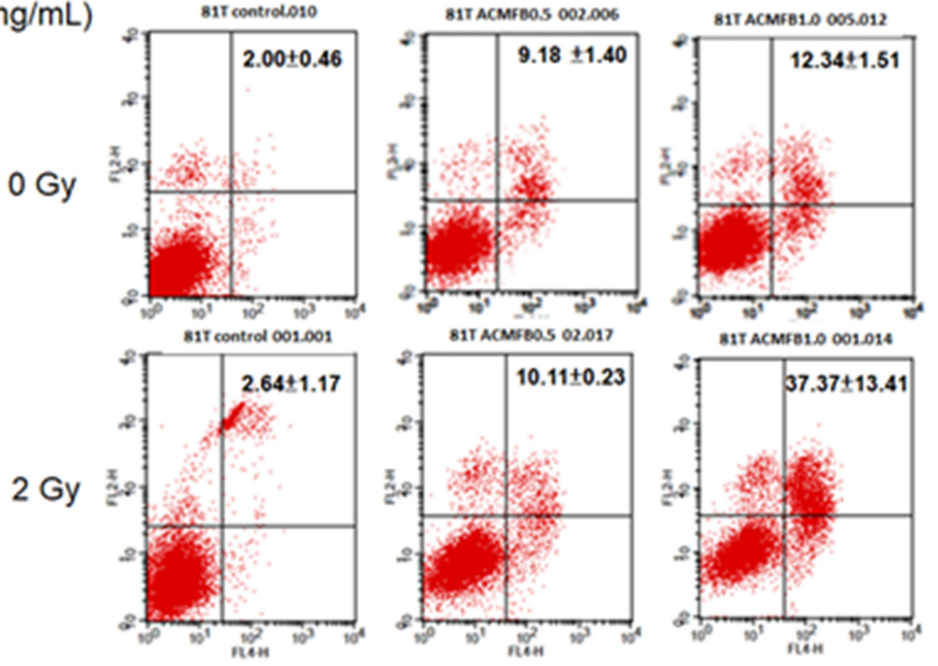

Figure 3 AC-MFB induced mitotic arrest morphology change and apoptosis of CE 8IT/VGH cell.

Notes: Cells were not treated (A, control) or treated with 0.5 and $1.0 \mathrm{mg} / \mathrm{mL}$ AC-MFB for $24 \mathrm{~h}$ (B), irradiation of 2 Gy (C), or AC-MFB plus irradiation (D). Arrows indicate representative cells characteristic of mitotic arrest. (E) Cellular apoptotic percentages induced by AC-MFB. Cell image was obtained by Liu's Stain and microscopy at magnification $\times 400$. Cell apoptosis percentages were determined by flow cytometry with Annexin-V/PI staining. Data are expressed as mean \pm SD for three independent experiments. Abbreviations: AC-MFB, Antrodia cinnamomea mycelial fermentation broth; Gy, gray; h, hours; PI, propidium iodine; SD, standard deviation.

OncoTargets and Therapy 2020:13 9101-9102 
concentration, radiation dose and time. This did mean some bands were rearranged and moved from their positions in the original Western blots. The upper bands which include pchk2, p-ATM, Rad51, KU70 and KU80 were part of the original experiments and the lower bands which include Cyclin B1, Cdc 2, p 21 and r-H2AX were added following peer review. The incorrect actin band was shown for the lower Western blots and the correct Figure 5 is shown below.

The authors apologize for these errors.

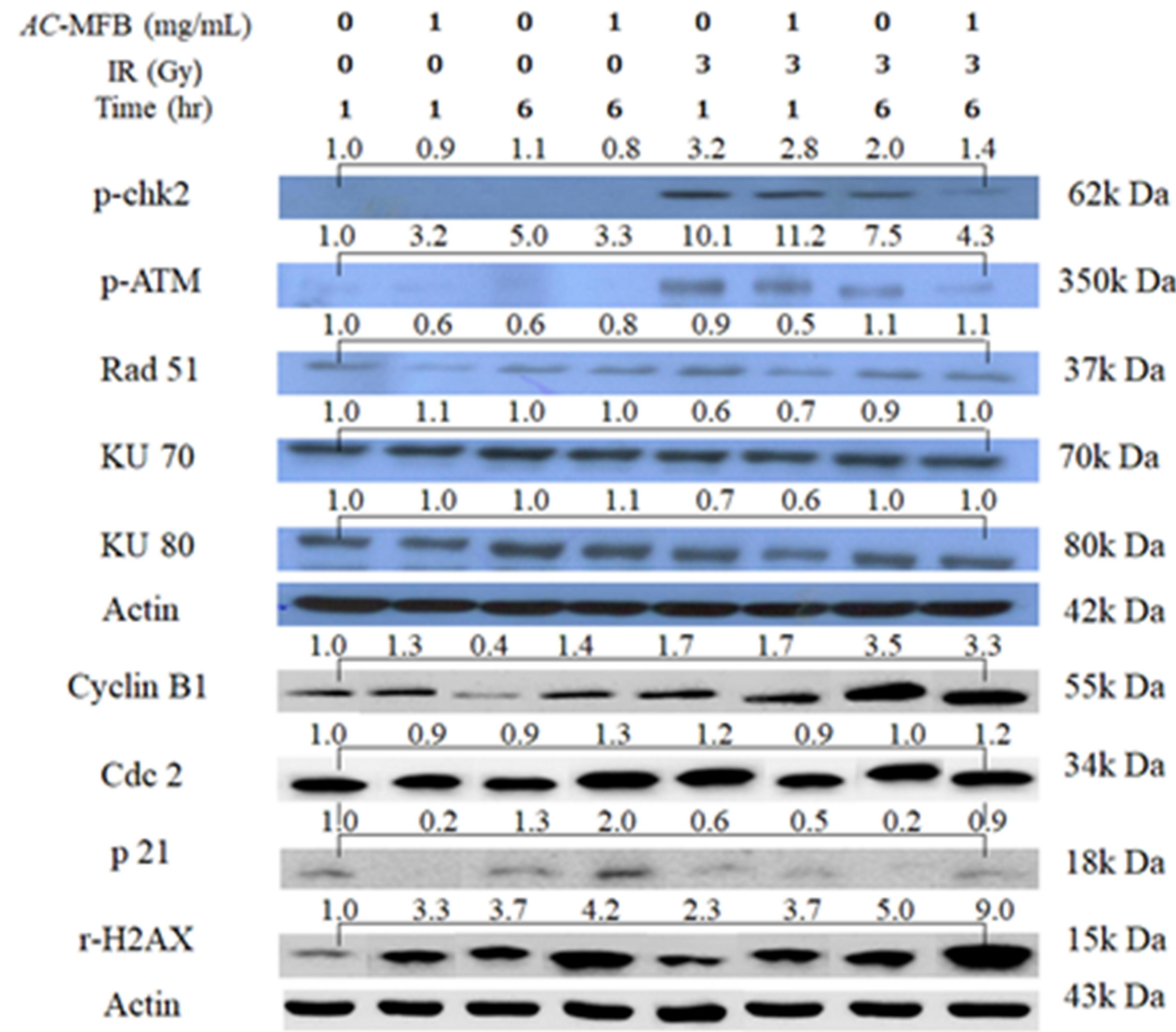

Figure 5 AC-MFB regulated p2I expression, phosphorylation of ATM kinase, and Chk2.

Notes: Cells were treated with vehicle (control), I.0 mg/mL AC-MFB for $24 \mathrm{~h}$, IR of $3 \mathrm{~Gy}$, or AC-MFB plus IR and then were lysed for the determination of the indicated protein levels by immunoblotting. Actin was used as internal control. The apparent molecular weights for detected proteins are indicated. The numeric data above the bar means the mean folds of Western blot data in different conditions compared to cells that were harvested at 0 min.

Abbreviations: AC-MFB, Antrodia cinnamomea mycelial fermentation broth; ATM, ataxia telangiectasia-mutated kinase; Chk2, checkpoint kinase 2; Gy, gray; h, hours; IR, irradiation; p-ATM, phosphorylated ATM; p-ChK2, phosphorylated Chk2.

\section{Publish your work in this journal}

OncoTargets and Therapy is an international, peer-reviewed, open access journal focusing on the pathological basis of all cancers, potential targets for therapy and treatment protocols employed to improve the management of cancer patients. The journal also focuses on the impact of management programs and new therapeutic agents and protocols on patient perspectives such as quality of life, adherence and satisfaction. The manuscript management system is completely online and includes a very quick and fair peer-review system, which is all easy to use. Visit http://www.dovepress.com/ testimonials.php to read real quotes from published authors. 